\title{
Effect of reed canary grass cultivation on greenhouse gas emission from peat soil at controlled rewetting
}

\author{
S. Karki, L. Elsgaard, and P. E. Lærke \\ Aarhus University, Department of Agroecology, Blichers Allé 20, 8830 Tjele, Denmark \\ Correspondence to: S. Karki (sandhya.karki@agrsci.dk)
}

Received: 7 August 2014 - Published in Biogeosciences Discuss.: 16 September 2014

Revised: 28 November 2014 - Accepted: 1 December 2014 - Published: 29 January 2015

\begin{abstract}
Cultivation of bioenergy crops in rewetted peatland (paludiculture) is considered as a possible land use option to mitigate greenhouse gas (GHG) emissions. However, bioenergy crops like reed canary grass (RCG) can have a complex influence on GHG fluxes. Here we determined the effect of RCG cultivation on GHG emission from peatland rewetted to various extents. Mesocosms were manipulated to three different ground water levels (GWLs), i.e. $0,-10$ and $-20 \mathrm{~cm}$ below the soil surface in a controlled semi-field facility. Emissions of $\mathrm{CO}_{2}$ (ecosystem respiration, ER), $\mathrm{CH}_{4}$ and $\mathrm{N}_{2} \mathrm{O}$ from mesocosms with RCG and bare soil were measured at weekly to fortnightly intervals with static chamber techniques for a period of 1 year. Cultivation of RCG increased both ER and $\mathrm{CH}_{4}$ emissions, but decreased the $\mathrm{N}_{2} \mathrm{O}$ emissions. The presence of RCG gave rise to 69,75 and $85 \%$ of total ER at $-20,-10$ and $0 \mathrm{~cm}$ GWL, respectively. However, this difference was due to decreased soil respiration at the rising GWL as the plant-derived $\mathrm{CO}_{2}$ flux was similar at all three GWLs. For methane, 70-95\% of the total emission was due to presence of RCG, with the highest contribution at $-20 \mathrm{~cm}$ GWL. In contrast, cultivation of RCG decreased $\mathrm{N}_{2} \mathrm{O}$ emission by $33-86 \%$ with the major reductions at -10 and $-20 \mathrm{~cm}$ GWL. In terms of global warming potential, the increase in $\mathrm{CH}_{4}$ emissions due to $\mathrm{RCG}$ cultivation was more than offset by the decrease in $\mathrm{N}_{2} \mathrm{O}$ emissions at -10 and $-20 \mathrm{~cm}$ GWL; at $0 \mathrm{~cm}$ GWL the $\mathrm{CH}_{4}$ emissions was offset only by $23 \%$. $\mathrm{CO}_{2}$ emissions from ER were obviously the dominant RCG-derived GHG flux, but aboveground biomass yields, and preliminary measurements of gross photosynthetic production, showed that ER could be more than balanced due to the photosynthetic uptake of $\mathrm{CO}_{2}$ by RCG. Our results support that RCG cultivation could be a good land use option in terms of mitigating GHG emission
\end{abstract}

from rewetted peatlands, potentially turning these ecosystems into a sink of atmospheric $\mathrm{CO}_{2}$.

\section{Introduction}

Peatlands cover $3 \%$ of the world's area but contain $30 \%$ of the soil organic carbon (Parish et al., 2008), signifying an important role in the global carbon cycle. About $15 \%$ of the world's peatlands have been drained for different human purposes, mostly for agriculture and forestry and to a lesser extent for peat extraction (Joosten, 2009). Drained peatlands are major sources of $\mathrm{CO}_{2}$ emissions and estimated to account for about $6 \%$ of the total anthropogenic $\mathrm{CO}_{2}$ emission (Joosten, 2009). In order to reduce the large emissions of $\mathrm{CO}_{2}$ from drained peatlands, extensive rewetting projects have been implemented in Europe and North America (Höper et al., 2008), and rewetted organic soils have been included in the guidelines for national greenhouse gas (GHG) inventories by the Intergovernmental Panel on Climate Change (IPCC, 2014). In addition, agricultural use of wet and rewetted peatlands for crop growth (paludiculture) is considered as a possible land use option that may indirectly reduce the $\mathrm{CO}_{2}$ emissions by biomass production for energy purposes (Joosten et al., 2012; Günther et al., 2014).

Reed canary grass (RCG) (Phalaris arundinacea) is one of the suitable biomass crops for paludiculture (Wichtmann and Tanneberger, 2011). It can be established from seeds as normal agricultural grass (Kandel et al., 2013b), but in some countries it is considered as an invasive species (Maurer et al., 2003). The plants thrive in wet soils due to aerenchyma tissues (Kercher and Zedler, 2004; Askaer et al., 2011) that transport oxygen to the roots in otherwise anaerobic 
soil compartments. However, cultivating wetland plants like RCG may influence the overall GHG balance by a combination of contrasting effects. First of all, RCG can stimulate the processes of GHG production by increasing the labile soil organic carbon pool, e.g. via root exudates (Ström et al., 2003; Bastviken et al., 2005). Next, the transport of oxygen to anaerobic zones stimulates heterotrophic degradation of organic matter, but at the same time stimulates oxidation of $\mathrm{CH}_{4}$ (Kao-Kniffin et al., 2010) and suppress $\mathrm{CH}_{4}$ production due to increase in redox potential (Laanbroek, 2010; SuttonGrier and Megonigal, 2011). RCG may further increase the emissions of reduced soil gases as the aerenchyma tissues act as a conduit for the direct transport of, for example, $\mathrm{CH}_{4}$ and $\mathrm{N}_{2} \mathrm{O}$ produced in soil (Joabsson et al., 1999; Jørgensen et al., 2012). Also, $\mathrm{RCG}$ can decrease $\mathrm{N}_{2} \mathrm{O}$ emissions by assimilation of mineral $\mathrm{N}$, which reduces the availability of electron acceptors (nitrate) for denitrifying microorganisms (Roobroeck et al., 2010). In summary, the introduction of RCG at rewetted peatlands may cause a change in the patterns and underlying mechanisms of GHG emission, which are rather complex.

In the natural state, GHG emissions from peatlands are predominantly controlled by the position (depth) of the water table (IPCC, 2014). Basically, due to slow diffusion of oxygen in water (10000 times slower than in air), ground water level (GWL) has a strong control on the oxic/anoxic soil boundary and thereby on the biogeochemical processes involved in GHG fluxes (Dinsmore et al., 2009; Karki et al., 2014). However, the presence of aerenchymatous plants may strongly interact with GWL in being decisive for the resulting GHG emissions from wet peatlands. The objective of the present study was to quantify the role of RCG cultivation on the resulting GHG emissions of $\mathrm{CO}_{2}, \mathrm{~N}_{2} \mathrm{O}$ and $\mathrm{CH}_{4}$ from peat soils rewetted to various extents. Such information is very important for understanding the total GHG balance from paludiculture and improve the basis for modelling future climate. To accomplish this, the GHG emissions of all three gases were measured in an annual study with peat soil mesocosms with RCG and bare soil rewetted to constant GWLs of $0,-10$ and $-20 \mathrm{~cm}$ in a controlled semi-field facility.

\section{Materials and methods}

\subsection{Site description}

Soil cores were collected from a fen peatland in the Nørre $\AA$ river valley, Denmark $\left(56^{\circ} 44^{\prime} \mathrm{N}, 9^{\circ} 68^{\prime} \mathrm{E}\right)$. The peatland was drained to a depth of $60-70 \mathrm{~cm}$ early in the 20th century and has since then been used for agricultural purposes. RCG experimental plots were established at the site in 2009 (Kandel et al., 2013b). The top soil layer $(0-20 \mathrm{~cm})$ at the study site had the following main properties: highly decomposed peat soil corresponding to $\mathrm{H} 9$ on the von Post scale; bulk density,
$0.27 \mathrm{~g} \mathrm{~cm}^{-3}$; total organic carbon, $37.8 \%$; and total nitrogen, $3.2 \%$ (Karki et al., 2014).

\subsection{Experimental design}

A total of 30 intact soil cores for the mesocosm study were collected in May 2012 by inserting PVC pipes of $60 \mathrm{~cm}$ depth and $30 \mathrm{~cm}$ diameter into the soil. Half of the soil cores were collected from RCG plots and the other half were collected from a grass field surrounding the RCG plots. The upper $5 \mathrm{~cm}$ of the soil and litter layer was removed from the grass field before inserting the PVC pipes, and the soil cores were kept bare during the experiment. The soil cores were retrieved with help of a mini excavator and transported to semi-field facilities at AU Foulum (Karki et al., 2014). The bottom of the PVC pipes was covered with fine-meshed net to allow for free water movement, and the pipes were then installed in plastic cylinders (diameter, $37 \mathrm{~cm}$; height, $70 \mathrm{~cm}$ ). The plastic cylinders were filled with gravel at the bottom $10 \mathrm{~cm}$ and the space between the PVC pipes and the wall of the cylinders $($ ca. $3 \mathrm{~cm}$ ) was filled with sand. The whole setup was then installed in a trench at the semi-field facility with the soil surface at ground level.

Mesocosms with bare soil and RCG were randomly divided into three groups and manipulated to three different GWLs of $0,-10$ and $-20 \mathrm{~cm}$ below the soil surface. The water table was adjusted by fitting a rubber tubing (diameter, $1 \mathrm{~cm}$ ) to the bottom of each plastic cylinder and placing the other end of the rubber tubing at different heights corresponding to the level of GWL treatment. Water was supplied in the space between the PVC pipes and the wall of the cylinders every day for $1 \mathrm{~h}$ by a drip irrigation system. Further details on mesocosm incubations and the semi-field facility can be found in Karki et al. (2014).

Due to poor regrowth of RCG (both under mesocosm and field conditions), initial weed biomass was uprooted and new RCG seeds were spread on 21 June 2012. RCG was fertilized with surface application of $0.6 \mathrm{~g} \mathrm{~N}, 0.1 \mathrm{~g} \mathrm{P}$ and $0.5 \mathrm{~g}$ $\mathrm{K}$ per mesocosm on 23 July 2012 (corresponding to $80 \mathrm{~kg}$ $\mathrm{N}, 13 \mathrm{~kg} \mathrm{P}$ and $77 \mathrm{~kg} \mathrm{Kha}^{-1}$ ). This fertilization rate corresponded to the rate applied in a previous study at the RCG field site from where the mesocosms were collected (Kandel et al., 2013a), except that the nitrogen rate was slightly increased in the mesocosm study as lower $\mathrm{N}$ mineralization was expected at higher GWLs. After the regrowth of RCG in spring 2013, RCG was fertilized with the same amount of fertilizer on 30 April and again in 28 June 2013. RCG plants were harvested twice, first on 29 October 2012 and then on 27 June 2013. In bare soil mesocosms, emerging weeds were uprooted and mosses were eliminated by application of iron sulfate $\left(\mathrm{FeSO}_{4}\right)$ on 29 August 2012. No fertilizer was added to bare soil mesocosms. 


\subsection{Gas measurements and flux calculation}

Dark PVC chambers (diameter, $30 \mathrm{~cm}$; height, $50 \mathrm{~cm}$ ) equipped with fans and pressure equilibration vents were used for the measurement of $\mathrm{CO}_{2}, \mathrm{CH}_{4}$ and $\mathrm{N}_{2} \mathrm{O}$ (Karki et al., 2014). Gas measurements were carried out between 10:00 and 13:00 at weekly to fortnightly intervals from July 2012 to July 2013. Four gas samples (10 mL) were drawn from the chamber headspace with polypropylene syringes during $45 \mathrm{~min}$ of chamber enclosure and transferred to evacuated $6 \mathrm{~mL}$ Exetainers. Gas samples were analysed with an Agilent 7890 gas chromatograph connected to a CTC CombiPAL automatic sample injection system (Agilent, Nærum, Denmark). Fluxes were calculated using the HMR method (Pedersen et al., 2010) in the statistical software $\mathrm{R}$ version 3.0.2 (R Core Team, 2013) as non-linear increase in GHG concentration over time was often observed during the non-steady-state chamber measurements (Davidson et al., 2002; Petersen et al., 2012). Thus, according to the statistical HMR analysis, fluxes were calculated either by non-linear or linear models (Pedersen et al., 2010). Out of the total of 435 fluxes for each $\mathrm{GHG}$, the non-linear approach was applied for 41,40 and $18 \%$ of $\mathrm{CO}_{2}, \mathrm{CH}_{4}$ and $\mathrm{N}_{2} \mathrm{O}$ fluxes from RCG mesocosms, respectively, and 22, 16 and $22 \%$ of $\mathrm{CO}_{2}, \mathrm{CH}_{4}$ and $\mathrm{N}_{2} \mathrm{O}$ fluxes from bare soil mesocosms, respectively. In bare soil at $0 \mathrm{~cm} \mathrm{GWL}$, approximately $3 \%$ of the $\mathrm{CH}_{4}$ fluxes were discarded due to episodic release of $\mathrm{CH}_{4}$ presumably by ebullition.

\subsection{Biomass measurement}

Biomass development was monitored through the nondestructive measurement of ratio vegetation index (RVI). RVI was determined for each mesocosm using a SpectroSense 2+ fitted with SKR1800 sensors (Skye Instruments, Powys, UK). The sensors measured the incident and reflected red light $(\mathrm{R})$ at $656 \mathrm{~nm}$ and the incident and reflected infrared light (NIR) at $778 \mathrm{~nm}$. RVI was then calculated as $\left(\mathrm{NIR}_{r} / \mathrm{NIR}_{i}\right) /\left(\mathrm{R}_{r} / \mathrm{R}_{i}\right)$, where the subscripts $i$ and $r$ denote the incident and reflected radiation. RVI has previously been used as a useful predicting factor for modelling ecosystem respiration (ER) and $\mathrm{CH}_{4}$ fluxes (Kandel et al., 2013a, b; Görres et al., 2014; Karki et al., 2014)

RVI measurements were done on the same days as GHG sampling, except in winter, when the soil was covered with snow or frozen. The total above-ground dry biomass from each mesocosm was also determined after each harvest by oven-drying the plant material at $60^{\circ} \mathrm{C}$ to constant weight. After the harvest in 2013, species composition from each mesocosm was determined on dry weight basis to quantify the contribution of volunteer weeds in the total biomass.

\subsection{Environmental parameters and pore water analysis}

Soil temperature at $5 \mathrm{~cm}$ depth and soil moisture was measured by means of temperature and time domain reflectometry (TDR) probes installed permanently in one of the five replicates for each GWL treatment. Soil temperature was measured automatically every hour, while soil moisture measurements with TDR (volumetric water content, VWC) were done on every gas sampling occasion. The instrumented mesocosms also had $\mathrm{Pt}$ probes installed at $20 \mathrm{~cm}$ depth to measure soil redox potential. Soil redox potential was measured at fortnightly intervals from mid-April to July 2013 with a portable $\mathrm{pH}$ meter (PHM220, Radiometer) by gently pushing a double-junction calomel reference electrode (REF251, Hach Lange) into the soil. Measured redox potential were converted to standard hydrogen electrode potential (Eh) by addition of $+245 \mathrm{mV}$ (Kjaergaard et al., 2012).

A piezometer (length, $65 \mathrm{~cm}$; diameter, $2 \mathrm{~cm}$ ) with the screen all the way down was installed in the instrumented mesocosms. Approximately $30 \mathrm{~mL}$ of soil water was sampled monthly from these piezometers, except for February to April 2013, when water inside the piezometers was frozen. Water samples were analysed for ammonium, nitrate and sulfate content. Ammonia and nitrate content were measured using an auto-analyser (Bran+Luebbe $\mathrm{GmbH}$, Norderstedt, Germany), and sulfate was determined via ion chromatography on a Dionex ICS-1500 IC system (Dionex Corp., Sunnyvale, CA, USA).

\subsection{Cumulative GHG fluxes}

For the mesocosms with RCG, $\mathrm{CO}_{2}$ emissions from ER were modelled as a function of GWL, temperature and biomass (RVI) by model 1 (Karki et al., 2014); for bare soil mesocosms, model 2 excluding RVI was applied:

$$
\begin{aligned}
& \mathrm{ER}=\left(b_{1}+b_{2} \mathrm{GWL}\right) \\
& \times \exp \left(b_{3}\left(\frac{1}{10-T_{0}}-\frac{1}{T-T_{0}}\right)\right) \times\left(b_{4}+\mathrm{RVI}\right), \\
& \mathrm{ER}=\left(b_{1}+b_{2} \mathrm{GWL}\right) \\
& \times \exp \left(b_{3}\left(\frac{1}{10-T_{0}}-\frac{1}{T-T_{0}}\right)\right)
\end{aligned}
$$

where $T_{0}$ is a notional zero respiration temperature, here fixed to $-46.02{ }^{\circ} \mathrm{C}$ (Lloyd and Taylor, 1994); $T$ is the air or soil temperature $\left({ }^{\circ} \mathrm{C}\right)$; RVI is the ratio vegetation index; GWL is water table depth below the soil surface $(\mathrm{cm})$; and $b_{1}, b_{2}, b_{3}$ and $b_{4}$ are model parameters.

All model parameters were estimated by non-linear regression in SigmaPlot 11 (Systat Software, Chicago, IL, USA). Using the obtained model parameters, continuous temperature data and linearly interpolated RVI data, hourly rates of $\mathrm{CO}_{2}$ emissions were reconstructed for each GWL. These hourly emissions values were summed to yield the annual flux from 10 July 2012 to 9 July 2013. The uncertainty of 


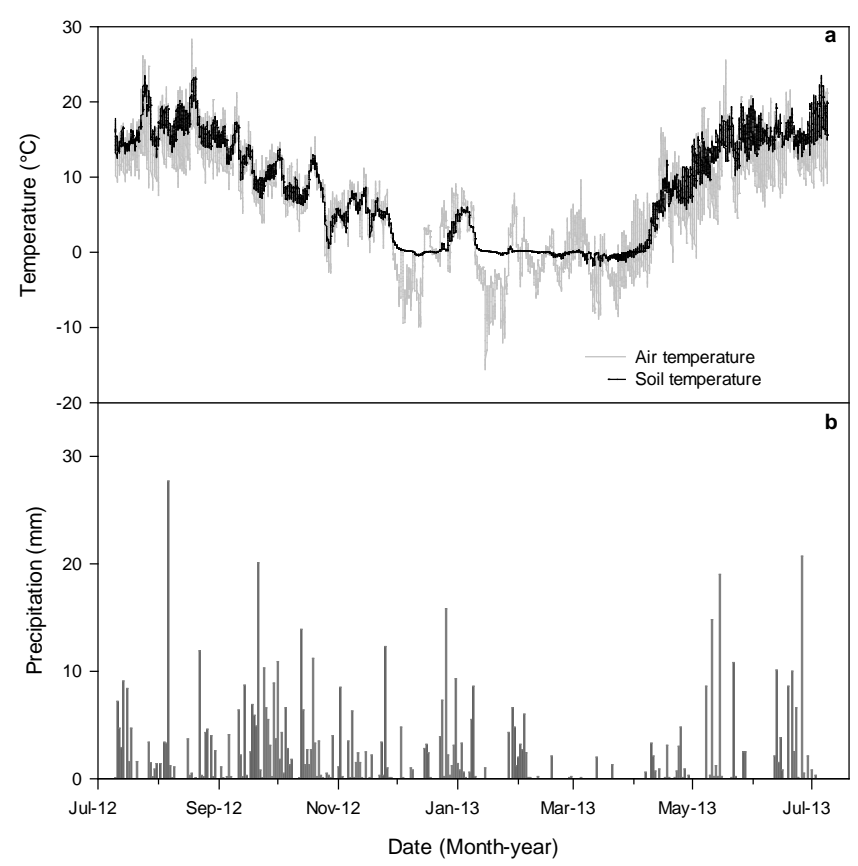

Figure 1. (a) Hourly air temperature at $2 \mathrm{~m}$ height at the semi-field facility and hourly average soil temperature at $5 \mathrm{~cm}$ depth across all mesocosm treatments, and (b) daily precipitation at the semi-field facility during the study period (July 2012 to July 2013).

annual fluxes was addressed by deriving the minimum and maximum cumulative fluxes from upper and lower values of model parameters \pm standard errors (SE) (Elsgaard et al., 2012). For model evaluation the Nash-Sutcliffe modelling efficiency (ME) was calculated according to

$\mathrm{ME}=1-\frac{\sum_{i=1}^{n}\left(\operatorname{Mes}_{i}-\operatorname{Mod}_{i}\right)^{2}}{\sum_{i=1}^{n}\left(\operatorname{Mes}_{i}-\overline{\operatorname{Mes}}\right)^{2}}$,

where $\mathrm{Mes}_{\mathrm{i}}$ and $\mathrm{Mod}_{\mathrm{i}}$ are measured and modelled values, respectively, and $\overline{\mathrm{Mes}}$ is the mean of measured values (Haefner, 2005).

Cumulative $\mathrm{CH}_{4}$ and $\mathrm{N}_{2} \mathrm{O}$ fluxes were calculated by linear interpolation between the sampling dates using the trapezoidal rule (Petersen et al., 2012). The linear interpolation method was used as there were no common models to predict $\mathrm{CH}_{4}$ and $\mathrm{N}_{2} \mathrm{O}$ fluxes for vegetated and bare soil plots. Cumulative fluxes were calculated for each individual mesocosm and then averaged for each GWL treatment $(n=5)$. Total GHG emissions were calculated by summing annual $\mathrm{CO}_{2}, \mathrm{CH}_{4}$ and $\mathrm{N}_{2} \mathrm{O}$ emissions at each GWL; $\mathrm{CH}_{4}$ and $\mathrm{N}_{2} \mathrm{O}$ emissions were converted to $\mathrm{CO}_{2}$ equivalents by multiplying by 28 and 265, respectively, according to the revised global warming potential (GWP) of the three GHGs (Myhre et al., 2013). The plant-derived total GHG emission at each GWL was estimated as the difference between the total GHG emissions from RCG mesocosms and bare soil mesocosms. The standard error of annual plant-derived GHG emissions was calculated following the law of error propagation as the square root of the sum of the squared standard error of plant and bare soil emissions.

\subsection{Statistical analysis}

Statistical analyses were done using R version 3.0.2 (R Core Team, 2013). Data were analysed using a linear mixed model including the fixed effect of vegetation (bare soil/RCG), GWL, date and their two-way interactions. The model also included the random effect of each experimental unit. Prior to analysis, $\mathrm{CH}_{4}$ and $\mathrm{N}_{2} \mathrm{O}$ flux data were log-transformed after addition of a constant (lowest detected fluxes of $\mathrm{CH}_{4}$ and $\mathrm{N}_{2} \mathrm{O}$ ) to obtain normal distribution and variance homogeneity. Dates were treated as repeated measurements by applying either compound symmetry structure (each dependent variable has constant covariance independent of time) or autocorrelation structure of order 1 (errors at adjacent time points are correlated) (Maxwell and Delaney, 2004). The best model was selected by use of Akaike's information criterion (AIC). For $\mathrm{CH}_{4}$ and $\mathrm{N}_{2} \mathrm{O}$, autocorrelation structure was selected, while compound symmetry was selected for $\mathrm{CO}_{2}$ fluxes.

A similar linear mixed model was run to determine the effect of GWL on RVI development. One-way ANOVA was used to test the difference in mean yield between the treatments. Significance of all tests was accepted at $P<0.05$.

\section{Results}

\subsection{Environmental conditions}

The average air temperature during the study period was $6.9^{\circ} \mathrm{C}$ and total precipitation was $667 \mathrm{~mm}$ (Fig. 1). Snowfall started in early December 2012 and was observed until the end of March 2013 with intermittent freezing and thawing events. The soil was frozen and covered with ice until mid-April 2013. The annual average soil temperature $(5 \mathrm{~cm}$ depth) in RCG treatments was $7.4,7.7$ and $7.6^{\circ} \mathrm{C}$ at $0,-10$ and $-20 \mathrm{~cm} \mathrm{GWL}$, respectively; for bare soil treatments it was $7.5,7.4$ and $7.9^{\circ} \mathrm{C}$ at $0,-10$ and $-20 \mathrm{~cm} \mathrm{GWL}$, respectively. The average volumetric soil water content during the measurement period was $82 \pm 5,67 \pm 3$, and $58 \pm 3 \%$ from RCG treatments at $0,-10$ and $-20 \mathrm{~cm} \mathrm{GWL}$, respectively, and $83 \pm 4,62 \pm 6$ and $55 \pm 7 \%$ from bare soil treatments at $0,-10$ and $-20 \mathrm{~cm}$ GWL, respectively (mean \pm standard deviation, $n=22$ ). Average soil redox potential was -115 , -27 and $40 \mathrm{mV}$ from RCG treatments at $0,-10$ and $-20 \mathrm{~cm}$ GWL, respectively, and $-118,-51$ and $151 \mathrm{mV}$ from bare soil treatments at $0,-10$ and $-20 \mathrm{~cm}$ GWL, respectively (Fig. 2). 


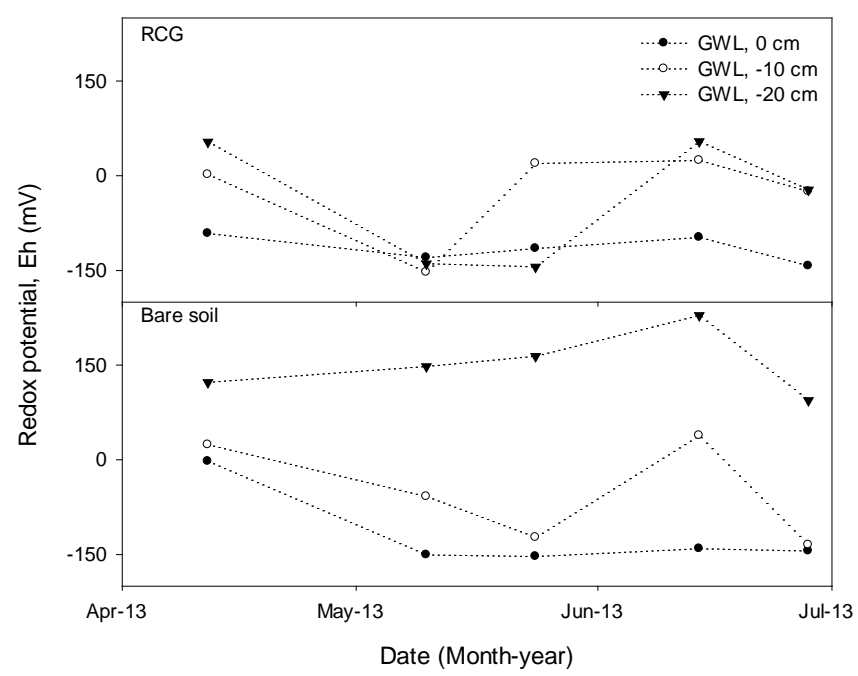

Figure 2. Redox potential (Eh) at different ground water levels (GWL) from reed canary grass (RCG) and bare soil mesocosms. Eh was measured at $20 \mathrm{~cm}$ soil depth from April to July 2013.

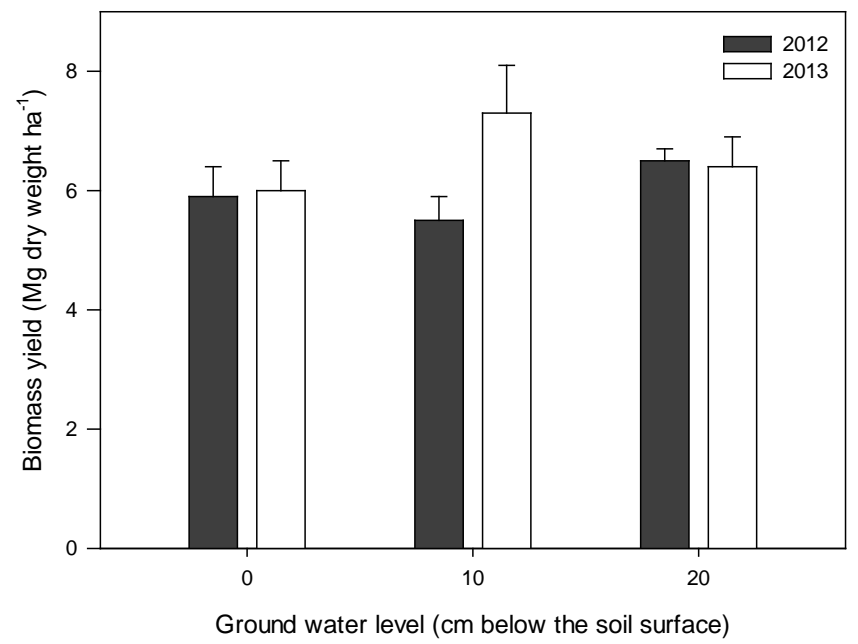

Figure 3. Mean dry biomass yield $\left(\mathrm{Mg} \mathrm{ha}^{-1}\right)$ from mesocosms at different ground water levels in 2012 and 2013. Error bars show standard error $(n=5)$.

\subsection{Biomass yield and RVI}

The mean biomass yield was 6.0 and $6.6 \mathrm{Mg} \mathrm{ha}^{-1}$ across all GWLs in 2012 and 2013, respectively (Fig. 3). During the first year there was a good stand of RCG, but during the second year weed biomass became established, especially at $0 \mathrm{~cm} \mathrm{GWL}$; this was notably marsh foxtail (Alopecurus geniculatus) and grasses (Poa sp.), which made an important contribution to the total biomass at the time of harvest.

The pattern of RVI development was similar among the different GWL treatments; peak values of RVI occurred in late August 2012, whereafter RVI started to decline due to

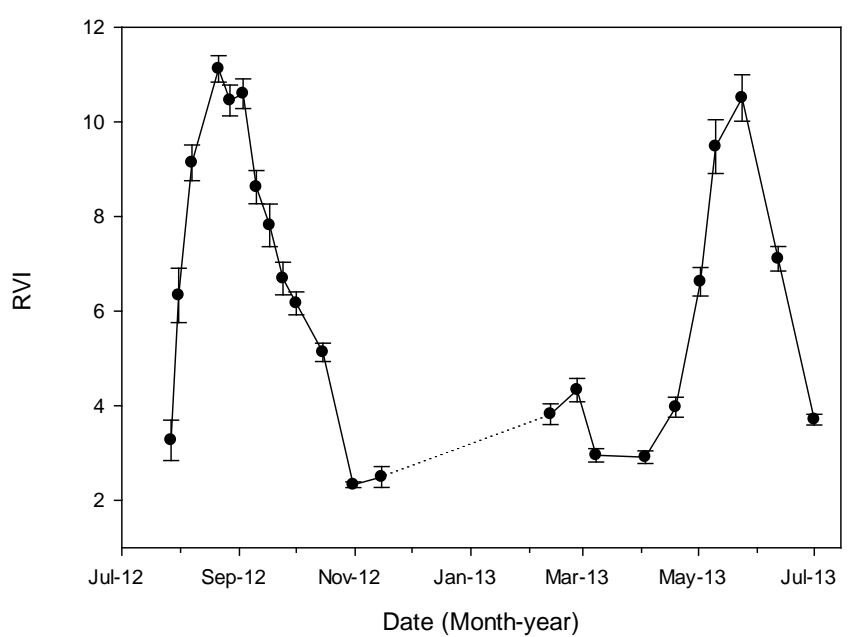

Figure 4. Average ratio vegetation index (RVI) development during the measurement period across all ground water levels. Error bars show standard error $(n=15)$. The dotted line represents the winter period, when RVI was not measured due to ice and snow.

plant senescence. RVI started to increase again during the regrowth of biomass in spring 2013 (Fig. 4).

\subsection{Pore water properties}

The annual variation in soil water sulfate concentrations ranged from 1.3 to $56.9 \mathrm{mg} \mathrm{L}^{-1}$. Generally, similar $\mathrm{SO}_{4}^{2-}$ concentrations were found in bare soil and RCG mesocosms at 0 and $-10 \mathrm{~cm}$ GWL, but at $-20 \mathrm{~cm}$ GWL consistently higher $\mathrm{SO}_{4}^{2-}$ concentrations were found in the bare soil mesocosms (Table 1). For ammonium the concentrations ranged from $<0.1$ to $10.2 \mathrm{~m} \mathrm{~L}^{-1}$, and higher $\mathrm{NH}_{4}^{+}$concentrations were generally found in bare soil mesocosms than in RCG mesocosms at 0 and $-10 \mathrm{~cm}$ GWL. In the bare soil treatments the level of $\mathrm{NH}_{4}^{+}$was lower at $-20 \mathrm{~cm} \mathrm{GWL}$ than at 0 and $-10 \mathrm{~cm}$ GWL, but in RCG treatments $\mathrm{NH}_{4}^{+}$concentrations were similar at all the three GWLs (Table 1). The concentration of nitrate was low $\left(<3.1 \mathrm{mg} \mathrm{L}^{-1}\right)$ across all treatments; the highest $\mathrm{NO}_{3}^{-}$levels were generally seen at bare soil treatments at $-20 \mathrm{~cm}$ GWL (Table 1).

\subsection{Measured GHG fluxes}

The emission of $\mathrm{CO}_{2}$ was measured as ER in RCG and bare soil treatments in order to evaluate the contribution of RCG in the total ER at the different GWLs. The emissions of $\mathrm{CO}_{2}$ were different between RCG and bare soil mesocosms $(P<0.001)$ and also between the three GWL treatments $(P<0.001)$ (Table 2). $\mathrm{CO}_{2}$ emissions decreased consistently with higher GWL both from RCG and bare soil mesocosms. The emissions showed expected seasonal variation with highest $\mathrm{CO}_{2}$ fluxes during summertime $(P$ $<0.001$ ) (Fig. 5a, b). $\mathrm{CO}_{2}$ emissions ranged from 20 to $485 \mathrm{mg} \mathrm{m}^{-2} \mathrm{~h}^{-1}$ across all GWLs in bare soil and from 55 
Table 1. Concentration of sulfate, ammonium and nitrate $\left(\mathrm{mgL}^{-1}\right)$ in ground water samples collected from piezometers from bare soil and reed canary grass (RGC) mesocosms at different ground water levels (GWL).

\begin{tabular}{llllllllll}
\hline Treatment & \multicolumn{2}{c}{$\mathrm{SO}_{4}^{2-}$} & $\left(\mathrm{mg} \mathrm{L}^{-1}\right)$ & at $\mathrm{GWL}$ & \multicolumn{2}{c}{$\mathrm{NH}_{4}^{+}$} & $\left(\mathrm{mgL}^{-1}\right)$ & at $\mathrm{GWL}$ & \multicolumn{2}{c}{$\mathrm{NO}_{3}^{-}\left(\mathrm{mgL}^{-1}\right)$ at GWL } \\
and date & $0 \mathrm{~cm}$ & $-10 \mathrm{~cm}$ & $-20 \mathrm{~cm}$ & $0 \mathrm{~cm}$ & $-10 \mathrm{~cm}$ & $-20 \mathrm{~cm}$ & $0 \mathrm{~cm}$ & $-10 \mathrm{~cm}$ & $-20 \mathrm{~cm}$ \\
\hline Bare soil & & & & & & & & & \\
26 Jul 2012 & 20.7 & 33.4 & 54.2 & 0.9 & 0.7 & $<0.1$ & 0.4 & 0.6 & 0.7 \\
24 Aug 2012 & 6.6 & 10.0 & 56.9 & 1.4 & 2.0 & 0.1 & 0.2 & 0.1 & 2.0 \\
26 Sep 2012 & 41.7 & 13.5 & 52.9 & 3.4 & 4.3 & 0.3 & 0.1 & $<0.1$ & 1.8 \\
5 Nov 2012 & 2.7 & 1.8 & 46.2 & 3.6 & 3.5 & 0.7 & $<0.1$ & 0.1 & 0.5 \\
30 Nov 2012 & 2.1 & 4.7 & 41.9 & 4.0 & 3.2 & 0.8 & $<0.1$ & $<0.1$ & 0.1 \\
4 Jan 2013 & 2.3 & 4.0 & 29.7 & 2.9 & 3.8 & 0.4 & 0.1 & 0.3 & 1.0 \\
6 May 2013 & 1.3 & 1.4 & 22.7 & 5.1 & 4.6 & 0.7 & 0.7 & 0.1 & 0.6 \\
11 Jun 2013 & 2.0 & 2.1 & 18.1 & 5.8 & 3.8 & 0.2 & $<0.1$ & $<0.1$ & 0.6 \\
16 Jul 2013 & 1.3 & 1.4 & 17.2 & 10.2 & 5.9 & 0.6 & $<0.1$ & $<0.1$ & 2.5 \\
\hline RCG & & & & & & & & & \\
26 Jul 2012 & 10.4 & 11.4 & 9.9 & 2.9 & 1.2 & 2.0 & 2.9 & 0.4 & 0.1 \\
24 Aug 2012 & 3.8 & 2.4 & 9.2 & 0.2 & 0.1 & 0.5 & $<0.1$ & $<0.1$ & 0.1 \\
26 Sep 2012 & 2.0 & 10.6 & 3.9 & 0.6 & 0.2 & 0.9 & 0.1 & 0.1 & 0.1 \\
5 Nov 2012 & 5.6 & 3.6 & 2.3 & 0.8 & 0.1 & 1.0 & $<0.1$ & $<0.1$ & $<0.1$ \\
30 Nov 2012 & 4.1 & 3.2 & 3.9 & 0.6 & 0.4 & 0.8 & 0.5 & 0.2 & 0.1 \\
4 Jan 2013 & 2.3 & 3.5 & 5.3 & 1.5 & 0.1 & 0.7 & 0.1 & 0.5 & 0.1 \\
6 May 2013 & 2.0 & 1.8 & 3.5 & 1.7 & 0.4 & 0.2 & $<0.1$ & 3.1 & $<0.1$ \\
11 Jun 2013 & 3.4 & 4.5 & 4.7 & 0.3 & 0.8 & 0.1 & $<0.1$ & 0.1 & 0.3 \\
16 Jul 2013 & 3.3 & 1.8 & 10.6 & 1.5 & 1.5 & 0.1 & 0.1 & $<0.1$ & 0.3 \\
\hline
\end{tabular}

Table 2. Statistical main effects of vegetation (i.e. reed canary grass cultivation or bare soil); ground water level (GWL); and date on fluxes of $\mathrm{CO}_{2}, \mathrm{CH}_{4}$ and $\mathrm{N}_{2} \mathrm{O}$ as explored with linear mixed models. Shown are Df (degrees of freedom) and $\mathrm{F}$ and $\mathrm{P}$ statistics.

\begin{tabular}{|c|c|c|c|c|c|c|c|c|c|}
\hline \multirow[t]{2}{*}{ Variables } & \multicolumn{3}{|c|}{$\mathrm{CO}_{2}$} & \multicolumn{3}{|c|}{$\mathrm{CH}_{4}$} & \multicolumn{3}{|c|}{$\mathrm{N}_{2} \mathrm{O}$} \\
\hline & Df & $F$ value & $P$ value & Df & $F$ value & $P$ value & Df & $F$ value & $P$ value \\
\hline Vegetation & 1 & 956.2 & $<0.001$ & 1 & 165.8 & $<0.001$ & 1 & 0.5 & $<0.001$ \\
\hline GWL & 2 & 32.2 & $<0.001$ & 2 & 15.4 & $<0.001$ & 2 & 3.1 & 0.02 \\
\hline Date & 28 & 75.6 & $<0.001$ & 28 & 25.8 & $<0.001$ & 28 & $<0.1$ & $<0.001$ \\
\hline
\end{tabular}

to $1700 \mathrm{mg} \mathrm{m}^{-2} \mathrm{~h}^{-1}$ in RCG treatments. Among the air and soil temperature at $5 \mathrm{~cm}, \mathrm{CO}_{2}$ emissions were better correlated with soil temperature in bare soil, but with the air temperature in RCG treatments.

Methane fluxes were significantly affected both by vegetation and GWL (Table 2). $\mathrm{CH}_{4}$ emissions were highest at $0 \mathrm{~cm}$ GWL both from RCG and bare soil treatments (Fig. 5c, d). $\mathrm{CH}_{4}$ emissions from RCG treatments showed temporal variation $(P<0.001)$ with highest emissions during summertime (Fig. 5c). Peak emissions of $\mathrm{CH}_{4}$ from RCG treatments were observed in August 2012 across all GWLs, ranging from 4.4 to $8.9 \mathrm{mg} \mathrm{CH}_{4} \mathrm{~m}^{-2} \mathrm{~h}^{-1}$. Between November and early April (i.e. winter season), $\mathrm{CH}_{4}$ emissions from $\mathrm{RCG}$ treatments were below $0.1 \mathrm{mg} \mathrm{m}^{-2} \mathrm{~h}^{-1}$, and even occasional uptake (25\% of total fluxes measured) of $\mathrm{CH}_{4}$ was recorded. From bare soil treatments, $\mathrm{CH}_{4}$ fluxes were generally low and fluctuated between apparent net emission and net uptake except for a few episodic peak events, generally from $0 \mathrm{~cm}$
GWL. These peak events were considered to represent unsystematic ebullition events.

$\mathrm{N}_{2} \mathrm{O}$ fluxes from RCG treatments were generally low, fluctuating in a range between -0.02 and $0.07 \mathrm{mg} \mathrm{m}^{-2} \mathrm{~h}^{-1}$ except for peak events after fertilizer application (Fig. 5e). Emission peaks of $0.4,0.7$ and $0.4 \mathrm{mg} \mathrm{N}_{2} \mathrm{O} \mathrm{m}^{-2} \mathrm{~h}^{-1}$ were observed at $0 \mathrm{~cm}$ GWL immediately after the first, second and third fertilization events, respectively. Smaller peak emissions of 0.4 and $0.2 \mathrm{mg} \mathrm{N}_{2} \mathrm{O} \mathrm{m}^{-2} \mathrm{~h}^{-1}$ were observed at $-10 \mathrm{~cm}$ GWL after the first and second fertilization event, but at $-20 \mathrm{~cm}$ GWL, peak emission after the fertilizer application was absent. $\mathrm{N}_{2} \mathrm{O}$ emissions from bare soil treatments generally were higher and ranged from -0.02 to $1.9 \mathrm{mg} \mathrm{m}^{-2} \mathrm{~h}^{-1}$. Most of the $\mathrm{N}_{2} \mathrm{O}$ emission in bare soil mesocosms was measured during the winter period from November 2012 to April 2013, accounting for more than $70 \%$ of the cumulative emission at 0 and $-10 \mathrm{~cm}$ GWL and more than $50 \%$ at $-20 \mathrm{~cm}$ GWL. 


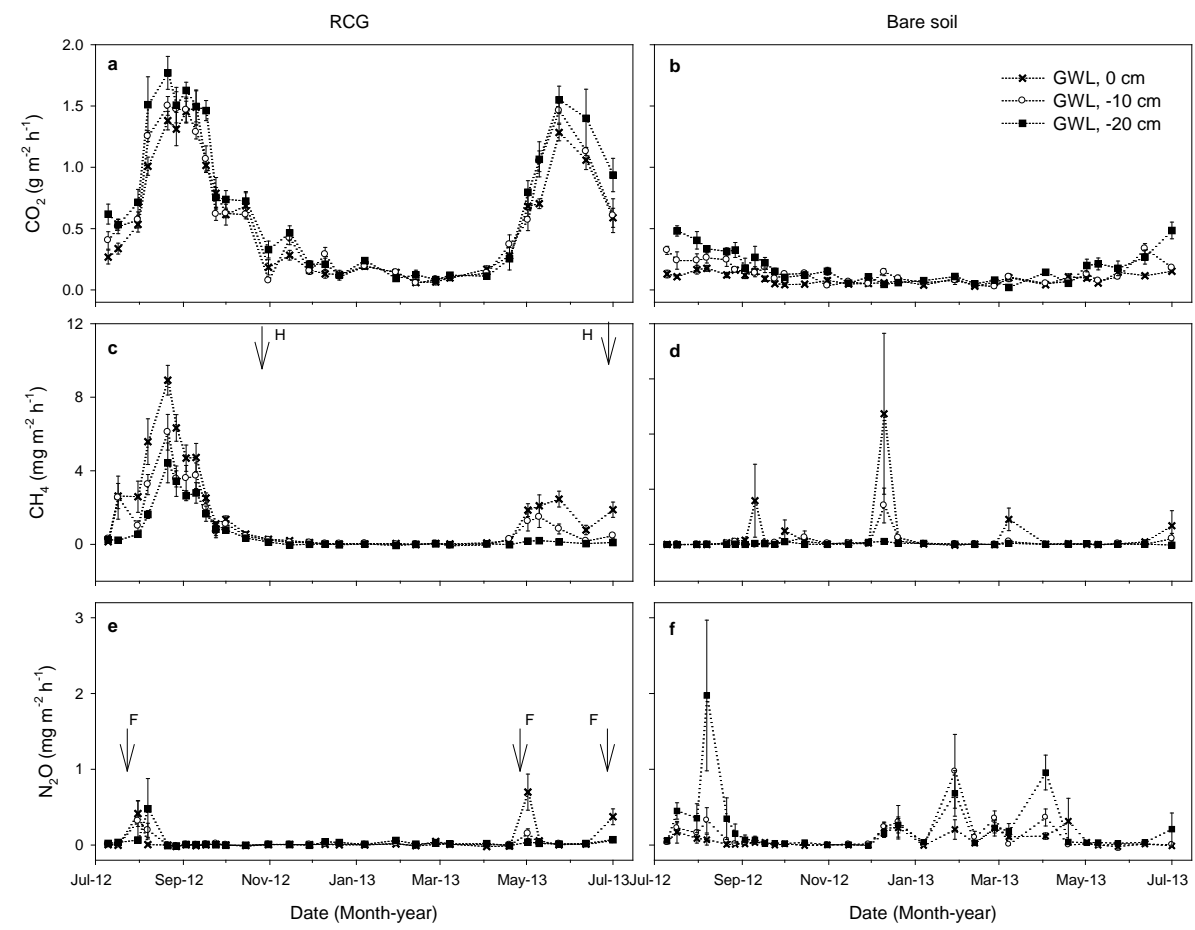

Figure 5. Time series of greenhouse gas fluxes from the rewetted peat soil mesocosms during July 2012 to July 2013 in treatments with RCG cultivation (left panels) and bare soil (right panels). Data are shown for (a, b) $\mathrm{CO}_{2}$ fluxes from ecosystem respiration, $(\mathbf{c}, \mathbf{d}) \mathrm{CH}_{4}$ fluxes, and $\left(\right.$ e, f) $\mathrm{N}_{2} \mathrm{O}$ fluxes. All data are mean and standard error of five replicates from each of the three ground water levels $(\mathrm{GWL})$ at $0,-10$ and $-20 \mathrm{~cm}$. Arrows marked $\mathrm{H}$ indicate the times of harvest, and arrows marked $\mathrm{F}$ indicate the times of mineral fertilization.
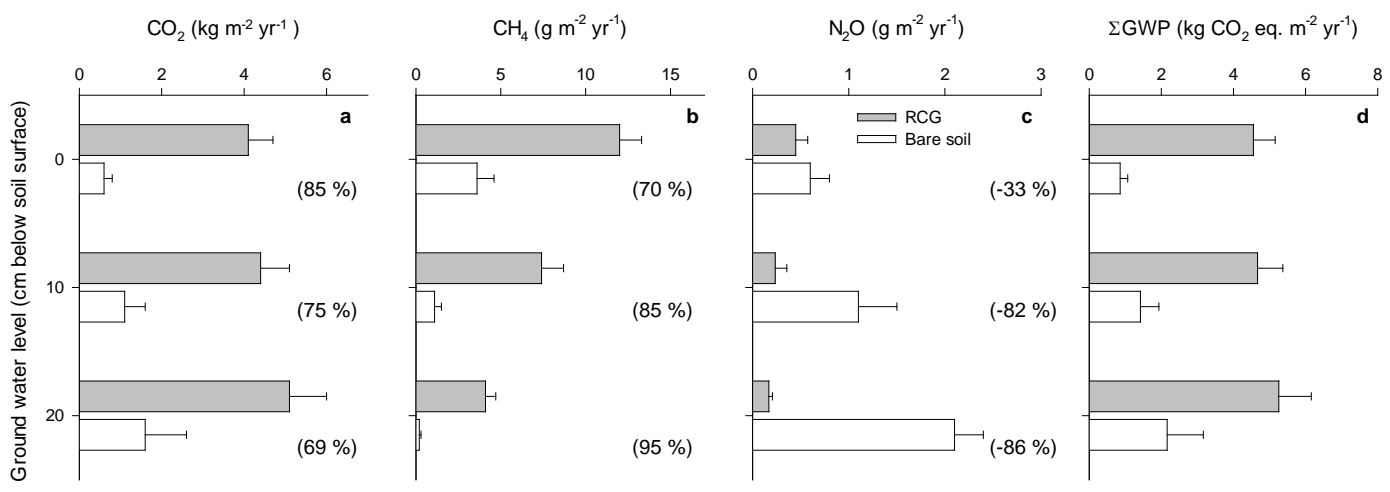

Figure 6. Annual fluxes of (a) $\mathrm{CO}_{2}$ from ecosystem respiration, (b) $\mathrm{CH}_{4}$, (c) $\mathrm{N}_{2} \mathrm{O}$ and (d) total global warming potential ( $\sum \mathrm{GWP}$ ) from the rewetted peat soil mesocosms during July 2012 to July 2013 in treatments with RCG cultivation (grey bars) and bare soil (white bars) at ground water levels of $0,-10$ and $-20 \mathrm{~cm}$. Error bars for $\mathrm{CO}_{2}$ data show the standard error (SE) derived from SE of model parameters. For $\mathrm{CH}_{4}$ and $\mathrm{N}_{2} \mathrm{O}$, data are shown as mean and SE of individual mesocosms $(n=5)$. Numbers in parentheses indicate the contribution of RCG in total emission at the different GWLs.

\subsection{Annual GHG emissions and contribution of plants to annual GHG emissions}

The estimated parameters for $\mathrm{CO}_{2}$ flux models are presented in Table 3, showing also that the modelling efficiency was considerably higher for the RCG treatments than the bare soil treatments. Annual $\mathrm{CO}_{2}$ emissions decreased consistently with raising GWL towards the soil surface both in RCG and bare soil treatments (Fig. 6a). In contrast, $\mathrm{CH}_{4}$ emissions increased systematically both from RCG and bare soil treatments in response to raising GWL (Fig. 6b). The annual $\mathrm{N}_{2} \mathrm{O}$ emissions showed a contrasting response to raising GWL in bare soil and RCG treatments; in bare soil treatments, lower $\mathrm{N}_{2} \mathrm{O}$ emissions occurred in response to raised GWL, but in RCG treatments there was a tendency of higher $\mathrm{N}_{2} \mathrm{O}$ emissions in response to raised GWL (Fig. 6c). 
Table 3. Parameter estimates $\left(b_{1}, b_{2}, b_{3}\right.$ and $\left.b_{4}\right)$ for $\mathrm{CO}_{2}$ flux models. Uncertainties shown in parentheses are standard error of parameter estimates. Also shown are correlation coefficients $(r)$ between observed and modelled data and modelling efficiencies (ME).

\begin{tabular}{|c|c|c|c|c|c|c|c|}
\hline Treatment & $\begin{array}{l}\mathrm{CO}_{2} \text { flux } \\
\text { model }\end{array}$ & $\begin{array}{l}b_{1} \\
\left(\mathrm{mgCO}_{2} \mathrm{~m}^{-2} \mathrm{~h}^{-1}\right)\end{array}$ & $\begin{array}{l}b_{2} \\
\left(\mathrm{mgCO}_{2} \mathrm{~m}^{-2} \mathrm{~h}^{-1} \mathrm{~cm}^{-1}\right)\end{array}$ & $\begin{array}{l}b_{3} \\
(\mathrm{~K})\end{array}$ & $b_{4}$ & $r$ & ME \\
\hline Reed canary grass & Model 1 & $49.6(3.8)$ & $0.4(0.1)$ & $259.1(15.5)$ & $5.0(0.7)$ & 0.90 & 0.82 \\
\hline Bare soil & Model 2 & $79.1(6.9)$ & $5.7(0.5)$ & $286.4(24.1)$ & $\mathrm{n} / \mathrm{a}$ & 0.68 & 0.46 \\
\hline
\end{tabular}

n/a: not applicable.

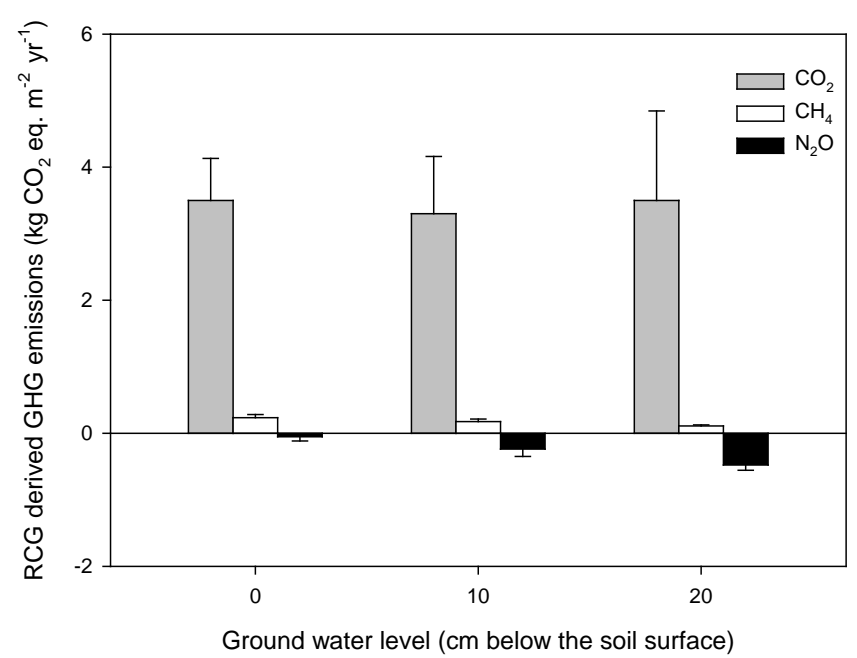

Figure 7. Plant-derived $\mathrm{CO}_{2}, \mathrm{CH}_{4}$ and $\mathrm{N}_{2} \mathrm{O}$ emissions at different ground water levels as compared in terms of $\mathrm{CO}_{2}$ equivalents $\left(\mathrm{CO}_{2}\right.$ eq.). Plant-derived emissions were estimated as the difference between the total emissions from RCG treatments and bare soil treatments.

The presence of plants contributed $69-85 \%$ of the total $\mathrm{CO}_{2}$ emissions from the RCG mesocosms (Fig. 6a). The highest contribution was observed at $0 \mathrm{~cm}$ GWL, and the contribution decreased at lower GWL. RCG likewise accounted for more than $70 \%$ of total $\mathrm{CH}_{4}$ emissions with the highest contribution of $95 \%$ observed at $-20 \mathrm{~cm}$ GWL. Thus, at this GWL $(-20 \mathrm{~cm}), \mathrm{CH}_{4}$ emission was negligible from bare soil treatments $\left(0.2 \mathrm{~g} \mathrm{CH}_{4} \mathrm{~m}^{-2} \mathrm{yr}^{-1}\right)$, whereas the emissions were substantial from RCG treatments $(4.1 \mathrm{~g}$ $\mathrm{CH}_{4} \mathrm{~m}^{-2} \mathrm{yr}^{-1}$ ). In contrast to $\mathrm{CO}_{2}$ and $\mathrm{CH}_{4}$ emissions, cultivation of RCG reduced the annual $\mathrm{N}_{2} \mathrm{O}$ emissions despite the application of mineral $\mathrm{N}$ fertilizer in RCG mesocosms (Fig. 6c). At -10 and $-20 \mathrm{~cm}$ GWL, RCG eliminated 82$86 \%$ of the $\mathrm{N}_{2} \mathrm{O}$ emissions as compared to bare soil treatments; from $0 \mathrm{~cm} \mathrm{GWL}$ the reduction corresponded to $33 \%$ of the $\mathrm{N}_{2} \mathrm{O}$ emissions. In terms of GWP, the increase in $\mathrm{CH}_{4}$ emissions due to RCG cultivation was more than offset by the decrease in $\mathrm{N}_{2} \mathrm{O}$ emissions at -10 and $-20 \mathrm{~cm}$ GWL, but apparently not at $0 \mathrm{~cm} \mathrm{GWL}$, where $\mathrm{CH}_{4}$ emissions were offset by only $23 \%$ by the decreased $\mathrm{N}_{2} \mathrm{O}$ emission (Fig. 7). $\mathrm{CO}_{2}$ emissions from ER, though, were the dominant RCGderived GHG fluxes (Fig. 7).

\section{Discussion}

During the present study, the effects of RCG cultivation on GHG emission from rewetted peatland were evaluated by comparison of planted and unplanted (bare soil) mesocosms. Mesocosms with RCG and bare soil (rather than, for example, mesocosms with native grasses) were compared in order to tentatively isolate the contribution of RCG in the measured GHG fluxes. One concern with using this plant exclusion method for GHG studies is the difference in soil moisture regime and temperature that may develop between planted and bare soil treatments, which may result in different decomposition rates of soil organic matter (Kuzyakov, 2006). With our experimental setup, we were able to control the GWL throughout the measurement period, and this resulted in soil moisture contents (VWC) that were similar between RCG and bare soil treatments at each GWL; this was generally also seen for the soil redox potential and pore water sulfate concentration at least at 0 and $-10 \mathrm{~cm}$ GWL. The average soil temperature difference between the RCG and bare soil treatments was found to be less than $1^{\circ} \mathrm{C}$; however during the annual study we observed some seasonal difference in soil temperature, especially during spring days (higher temperature in RCG treatments) and summer days (lower temperature in RCG treatments), which was attributed to the RCG cultivation. However, the differences in moisture and temperature regime between the planted and bare soil mesocosms were considered to be modest and acceptable for an evaluation of the effects of RCG on total GHG emissions.

Monitoring of environmental variables was achieved by instrumentation of one out of five replicate mesocosms at each GWL. We assumed that the measured variables were representative of all replicates and that the instrumentation did not lead to any bias. This was substantiated by the absence of any systematic deviations in measured GHG fluxes from the instrumented and non-instrumented replicates. Thus, the average difference in annual fluxes with and without instrumentation was less than $15 \%$.

\section{1 $\mathrm{CO}_{2}$ emissions}

Plants can enhance $\mathrm{CO}_{2}$ flux from ER directly by aboveand below-ground respiration and indirectly by enhancing the decomposition of soil organic matter by the supply of easily degradable root exudates to the soil (priming effect) (Kuzyakov et al., 2001; Van Huissteden et al., 2006). In 
vegetated soils, ER is essentially balanced by photosynthetic $\mathrm{CO}_{2}$ uptake, and therefore $\mathrm{CO}_{2}$ emissions from ER do not represent the net ecosystem exchange (NEE) of $\mathrm{CO}_{2}$. Rather than quantifying NEE, an important result of the present study was that plant-derived ER from RCG mesocosms (the major part of total $\mathrm{CO}_{2}$ emissions) was similar at all three GWLs (Fig. 7), substantiating the results of Lafleur et al. (2005) and Riutta et al. (2007), who reported autotrophic respiration to be independent of water table depth. Thus, the observed increase (from 69 to $85 \%$ ) in total ER with rising GWL was promoted mainly by decreasing soil respiration at the higher GWL (Fig. 6). The observed contribution of RCG to total $\mathrm{CO}_{2}$ emissions was higher than the values of $55 \%$ previously reported by Shurpali et al. (2008). However, the results of Shurpali et al. (2008) were obtained for a drained peatland with an average GWL of $-65 \mathrm{~cm}$, which would favour aerobic soil respiration to a larger extent than in our soils, which had a GWL no deeper than $-20 \mathrm{~cm}$. In accordance with this we also observed a larger soil respiration at $-20 \mathrm{~cm}$ than at $0 \mathrm{~cm}$ GWL.

\subsection{Methane emissions}

Methane fluxes from soil is the result of $\mathrm{CH}_{4}$ production, consumption and transport (Lai, 2009). Plants play a key role in $\mathrm{CH}_{4}$ fluxes as they have the potential to influence all three processes (Joabsson et al., 1999). $\mathrm{CH}_{4}$ emissions were higher from RCG than bare soil treatments even though the GWL was raised to the soil surface. Plant roots release organic compounds to soil, which are easily available carbon sources to anaerobic microbial consortia eventually producing the precursors (acetate or $\mathrm{H}_{2} / \mathrm{CO}_{2}$ ) for methanogenesis (Ström et al., 2003). Such fresh organic carbon is suggested to be an important substrate for methanogenesis as peat carbon is shown to be more recalcitrant to anaerobic decomposition (Tuittila et al., 2000; Hahn-Schöfl et al., 2011).

Methane produced in soil can be emitted to the atmosphere by diffusion, ebullition (release of gas bubbles) and plant-mediated transport (Whalen, 2005; Lai, 2009). Indeed, RCG can transport $\mathrm{CH}_{4}$ from soil to the atmosphere directly through its aerenchyma tissue, thereby bypassing the microbial methane oxidation layer in the soil. On an annual basis it has been estimated that RCG may actually transport $70 \%$ of the total $\mathrm{CH}_{4}$ emissions from a natural wetland in Denmark (Askaer et al., 2011). In the absence of plant-mediated transport, diffusion would expectedly be the dominant pathway of $\mathrm{CH}_{4}$ emissions in bare soil treatments. $\mathrm{CH}_{4}$ transport through diffusion is a slow but important process for bringing $\mathrm{CH}_{4}$ in contact with the $\mathrm{CH}_{4}$ oxidizing microbial community (Whalen 2005; Lai 2009). In our study there were negligible $\mathrm{CH}_{4}$ emissions from bare soil at $-20 \mathrm{~cm}$ GWL, aligning with the results of Schäfer et al. (2012), who reported this drainage depth to be sufficient to suppress diffusive $\mathrm{CH}_{4}$ emissions due to methane oxidation and reduced methanogenesis.
The transport of oxygen by aerenchyma plants to anoxic soil compartments has been reported to increase the redox potential, which could suppress $\mathrm{CH}_{4}$ emission (Sutton-Grier and Megonigal, 2011). However, in our study neither the redox potential nor the sulfate content was consistently increased by the presence of plants, suggesting the role of substrate availability and transport of $\mathrm{CH}_{4}$ through $\mathrm{RCG}$ to be the more important factors for controlling $\mathrm{CH}_{4}$ emissions from the RCG treatments.

It is possible that we could have underestimated the total $\mathrm{CH}_{4}$ emission from bare soil treatments at $0 \mathrm{~cm}$ GWL as episodic $\mathrm{CH}_{4}$ release through ebullition was not taken into account in the annual balance. Ebullition events were identified by occasional erratic time courses of $\mathrm{CH}_{4}$ concentrations during the flux measurements; however as these events were generally associated with the initial (time 0 and $15 \mathrm{~min}$ ) chamber gas samplings it was believed to represent artifacts created during chamber deployment. However, episodic release of $\mathrm{CH}_{4}$ may be more important in bare soil than in vegetated soil, as plants may reduce the soil concentration of $\mathrm{CH}_{4}$ by mediating $\mathrm{CH}_{4}$ transport and also by rhizospheric oxidation of $\mathrm{CH}_{4}$; these processes reduce the potential formation of $\mathrm{CH}_{4}$ bubbles (Chanton, 2005). With the observed episodic $\mathrm{CH}_{4}$ release tentatively accounted for, a total of $0.04 \mathrm{~g} \mathrm{~m}^{-2}$ of $\mathrm{CH}_{4}$ was released during the study; this was a negligible contribution $(<1 \%)$ to the annual $\mathrm{CH}_{4}$ flux from bare soil at $0 \mathrm{~cm}$ GWL. However, as ebullition events are short-lived and unsystematic, they could easily be missed with the chamber measurements (Coulthard et al., 2009).

\section{3 $\quad \mathrm{N}_{2} \mathrm{O}$ emissions}

Annual fluxes of $\mathrm{N}_{2} \mathrm{O}$ (0.2 to $\left.0.4 \mathrm{~g} \mathrm{~N}_{2} \mathrm{O} \mathrm{m}^{-2} \mathrm{yr}^{-1}\right)$ from RCG mesocosms were within the range $(-0.4$ to $0.8 \mathrm{~g}$ $\mathrm{N}_{2} \mathrm{O} \mathrm{m}^{-2} \mathrm{yr}^{-1}$ ) reported for undisturbed Danish riparian wetland (Audet et al., 2014). However, annual fluxes were higher in bare soil ( 0.6 to $2.1 \mathrm{~g} \mathrm{~N}_{2} \mathrm{O} \mathrm{m}^{-2} \mathrm{yr}^{-1}$ ) as compared to RCG treatments. Thus, RCG decreased the annual $\mathrm{N}_{2} \mathrm{O}$ emissions, contradictory to the finding of Hyvönen et al. (2009), where fertilization in RCG increased the $\mathrm{N}_{2} \mathrm{O}$ emissions by $90 \%$ as compared to bare soil. However, in the study by Hyvönen et al. (2009), $\mathrm{N}_{2} \mathrm{O}$ emissions were quite low $\left(0.01 \mathrm{~g} \mathrm{~N}_{2} \mathrm{O} \mathrm{m}^{-2} \mathrm{yr}^{-1}\right)$ from the soil without vegetation. Their site was an abandoned peatland (Hyvönen et al., 2009) probably with limited nitrification because of a high $\mathrm{C} / \mathrm{N}$ ratio (42.3) (Klemedtsson et al., 2005) compared to our peat soil with rich $\mathrm{N}$ content (3.2\%) and a low $\mathrm{C} / \mathrm{N}$ ratio (11.6). Thus, the ecosystem studied by Hyvönen et al. (2009) might have been more $\mathrm{N}$-limited at the unfertilized sites than was the case for our study site.

The effect of RCG cultivation on $\mathrm{N}_{2} \mathrm{O}$ emissions was highly dependent upon the GWL. The least effect of RCG cultivation on $\mathrm{N}_{2} \mathrm{O}$ emissions was observed at $0 \mathrm{~cm}$ GWL, due to peak emissions observed after fertilization. Peak emission observed after fertilization events suggests that $\mathrm{N}_{2} \mathrm{O}$ 
emission was limited by mineral $\mathrm{N}$ content at $0 \mathrm{~cm}$ GWL. Saari et al. (2013) and Silvan et al. (2002) also reported a significant increase in $\mathrm{N}_{2} \mathrm{O}$ emission after addition of inorganic nitrogen in riparian wetland due to favourable conditions for denitrification.

Previous studies have reported that winter emissions significantly contributed to annual $\mathrm{N}_{2} \mathrm{O}$ emissions (Maljanen et al., 2004; Regina et al., 2004). Such emissions in winter have been related to the physical release of $\mathrm{N}_{2} \mathrm{O}$ that is produced and trapped under frozen surface layers as well as the emissions of newly produced $\mathrm{N}_{2} \mathrm{O}$ (de novo emissions) at the onset of thaw stimulated by increased biological activity and changes in physical and chemical soil conditions (Risk et al., 2013). Significant emissions at all GWLs were observed in winter from bare soil treatments, but not from RCG treatments. After harvesting, there was regrowth of RCG and also other volunteer grasses which survived throughout the winter and which may have competed with microorganisms for available N. Maljanen et al. (2004) also observed higher $\mathrm{N}_{2} \mathrm{O}$ emissions from bare soil as compared to vegetated plots during winter and likewise related the low emission in vegetated plots to low mineral $\mathrm{N}$ content due to uptake of nitrate by plants. Bare soil treatments indeed had a higher availability of mineral $\mathrm{N}$ (Table 1), and could be more prone to physical damage by freeze and thaw cycles due to lack of plant cover; both these factors stimulate the biological activities related to $\mathrm{N}_{2} \mathrm{O}$ emissions as also substantiated by the observed slight increase in $\mathrm{CO}_{2}$ emissions coinciding with increased $\mathrm{N}_{2} \mathrm{O}$ emission, especially at 0 and $-10 \mathrm{~cm}$ GWL.

\subsection{Effect of RCG cultivation on GHG balance from rewetted peatland}

Two of the major concerns of growing wetland plants like RCG in rewetted peatland are the possible increase in $\mathrm{CH}_{4}$ emissions due to supply of fresh plant material and transport of $\mathrm{CH}_{4}$ by aerenchyma tissue (Ström et al., 2003; Askaer et al., 2011) and the possible increase in $\mathrm{N}_{2} \mathrm{O}$ due to application of $\mathrm{N}$ fertilizers (Maljanen et al., 2010). However, in the present experiment, cultivation of RCG decreased $\mathrm{N}_{2} \mathrm{O}$ emission to an extent that could offset the increase in $\mathrm{CH}_{4}$ emission at -10 and $-20 \mathrm{~cm}$ GWL, but apparently not at $0 \mathrm{~cm}$ GWL - the latter case being due to peak emissions in $\mathrm{N}_{2} \mathrm{O}$ after fertilization events in RCG. This result suggests that emissions at $0 \mathrm{~cm}$ GWL can be reduced by reducing the $\mathrm{N}$ fertilization rate. Further studies are needed to assess the optimum amount and timing of fertilization required for optimum growth of RCG with acceptable $\mathrm{N}_{2} \mathrm{O}$ emissions. Emissions of $\mathrm{N}_{2} \mathrm{O}$ caused by $\mathrm{N}$ fertilization should not offset the benefit of fossil fuel substitution obtained by the fertilizer-induced increase of biomass production (Kandel et al., 2013a). Regarding the overall GHG emission, the $\mathrm{CO}_{2}$ emissions from ER was clearly the dominant RCG-derived GHG flux. However, $\mathrm{CO}_{2}$ flux from ER would to a large extent be counterbalanced by gross photosynthesis, which, as expected, was similar at all GWL treatments (based on the similar biomass yields), though $\mathrm{CO}_{2}$ flux from photosynthesis was not measured in this annual study. However, a photosynthetic uptake of $6.2 \mathrm{~kg} \mathrm{CO}_{2} \mathrm{~m}^{-2}$ was measured from RCG mesocosms at $0 \mathrm{~cm}$ GWL during the growing season from May to September 2013 (S. Karki, unpublished data), reflecting that RCG potentially can turn the rewetted ecosystem into a sink of $\mathrm{CO}_{2}$ from an atmospheric perspective. Adaptation or selection of RCG varieties that thrive especially well under distinct climate and shallow GWL conditions could further help to improve the GHG balance of paludiculture with RCG.

\section{Conclusions}

The present study is, to our knowledge, the first to compare the annual GHG emission from RCG and bare soil treatments of rewetted peatland at controlled GWL. The following conclusions were derived: (i) soil respiration decreased with increasing GWL from -20 to -10 to $0 \mathrm{~cm}$, but RCG-derived ER was similar at all three GWLs, resulting in the highest contribution of RCG to total ER ( $85 \%$ ) at $0 \mathrm{~cm}$ GWL; (ii) cultivation of RCG increased $\mathrm{CH}_{4}$ emission at all GWLs, but relatively most at $-20 \mathrm{~cm}$ GWL; (iii) $\mathrm{N}_{2} \mathrm{O}$ emissions decreased due to RCG cultivation, especially during winter - winter emissions were a more important component of annual emission from bare soil than from RCG treatments; (iv) in terms of GWP, the increase in $\mathrm{CH}_{4}$ emissions due to RCG cultivation was more than offset by the decrease in $\mathrm{N}_{2} \mathrm{O}$ emissions at -10 and $-20 \mathrm{~cm} \mathrm{GWL}$; and (v) $\mathrm{CO}_{2}$ emissions from ER (the dominant RCG-derived GHG flux) could be balanced by photosynthetic $\mathrm{CO}_{2}$ uptake at all three GWLs, as indicated by the large and similar above-ground biomass yields at all GWLs, signifying a potential of RCG cultivation to turn the rewetted peatland into a sink of atmospheric $\mathrm{CO}_{2}$.

Acknowledgements. The study was partly supported by the Danish Centre for Food and Agriculture (DCA) as a part of the BioBase programme. The authors like to thank Sanmohan Baby for statistical advice. We are also grateful for the technical support we received from Bodil Stensgaard, Finn Henning Christensen, Holger Bak, Jørgen M. Nielsen and Stig T. Rasmussen.

Edited by: P. Stoy

\section{References}

Askaer, L., Elberling, B., Friborg, T., Jørgensen, C. J., and Hansen, B. U.: Plant-mediated $\mathrm{CH}_{4}$ transport and $\mathrm{C}$ gas dynamics quantified in-situ in a Phalaris arundinacea-dominant wetland, Plant Soil, 343, 287-301, 2011.

Audet, J., Hoffmann, C. C., Andersen, P. M., Baattrup-Pedersen, A., Johansen, J. R., Larsen, S. E., Kjaergaard, C., and Elsgaard, 
L.: Nitrous oxide fluxes in undisturbed riparian wetlands located in agricultural catchments: Emission, uptake and controlling factors, Soil Biol. Biochem., 68, 291-299, 2014.

Bastviken, S. K., Eriksson, P. G., Premrov, A., and Tonderski, K.: Potential denitrification in wetland sediments with different plant species detritus, Ecol. Eng., 25, 183-190, 2005.

Chanton, J. P.: The effect of gas transport on the isotope signature of methane in wetlands, Org. Geochem., 36, 753-768, 2005.

Coulthard, T. J., Baird, A. J., Ramirez, J., and Waddington, J. M.: Methane dynamics in peat: Importance of shallow peats and a novel reduced-complexity approach for modeling ebullition, in: Carbon Cycling in Northern Peatlands, edited by: Baird, A. J., Belyea, L. R., Comas, X., Reeve, A. S., and Slater, L. D., American Geophysical Union, Washington, DC, 173-185, 2009.

Davidson, E. A., Savage, K., Verchot, L. V., and Navarro, R.: Minimizing artifacts and biases in chamber-based measurements of soil respiration, Agric. For. Meteorol., 113, 21-37, 2002.

Dinsmore, K. J., Skiba, U. M., Billett, M. F., and Rees, R. M.: Effect of water table on greenhouse gas emissions from peatland mesocosms, Plant Soil, 318, 229-242, 2009.

Elsgaard, L., Görres, C.-M., Hoffmann, C. C., Blicher-Mathiesen, G., Schelde, K., and Petersen, S. O.: Net ecosystem exchange of $\mathrm{CO}_{2}$ and carbon balance for eight temperate organic soils under agricultural management, Agr. Ecosyst. Environ., 162, 5267, 2012.

Görres, C. M., Kutzbach, L., and Elsgaard, L.: Comparative modeling of annual $\mathrm{CO}_{2}$ flux of temperate peat soils under permanent grassland management, Agr. Ecosyst. Environ., 186, 64-76, 2014.

Günther, A., Huth, V., Jurasinski, G., and Glatzel, S.: The effect of biomass harvesting on greenhouse gas emissions from a rewetted temperate fen, GCB Bioenergy, doi:10.1111/gcbb.12214, 2014.

Haefner, J. W.: Modelling Biological Systems: Principles and Applications, 2nd Edn., Springer, New York, NY, 2005.

Hahn-Schöfl, M., Zak, D., Minke, M., Gelbrecht, J., Augustin, J., and Freibauer, A.: Organic sediment formed during inundation of a degraded fen grassland emits large fluxes of $\mathrm{CH}_{4}$ and $\mathrm{CO}_{2}$, Biogeosciences, 8, 1539-1550, doi:10.5194/bg-8-15392011, 2011.

Höper, H., Augustin, J., Cagampan, J. P., Drösler, M., Lundin, L., Moors, E., Vasander, H., Waddington, J. M., and Wilson, D.: Restoration of peatlands and greenhouse gas balances, in: Peatlands and Climate Change, edited by: Starck, M., International Peat Society, Saarijärvi, Finland, 182-210, 2008.

Hyvönen, N. P., Huttunen, J. T., Shurpali, N. J., Tavi, N. M., Repo, M. E., and Martikainen, P. J.: Fluxes of nitrous oxide and methane on an abandoned peat extraction site: effect of reed canary grass cultivation, Bioresoure Technol., 100, 4723-4730, 2009.

IPCC: 2013 Supplement to the 2006 IPCC Guidelines for National Greenhouse Gas Inventories: Wetlands in, edited by: Hiraishi, T., Krug, T., Tanabe, K., Srivastava, N., Baasansuren, J., Fukuda, M., and Troxler, T. G., IPCC, Switzerland, 2014.

Joabsson, A., Christensen, T. R., and Wallen, B.: Vascular plant controls on methane emissions from northern peatforming wetlands, Trends Ecol. Evol., 14, 385-388, 1999.

Joosten, $\mathrm{H}$.: The Global Peatland $\mathrm{CO}_{2}$ Picture: peatland status and drainage related emissions in all countries of the world, Wetland International, Ede., 2009.
Joosten, H., Tapio-Biström, M.-L., and Tol, S.: Peatlands-guidance for climate change mitigation through conservation, rehabilitation and sustainable use, Food and Argiculture Organisation of the United Nations and Wetlands International, Rome, Italy, 2012.

Jørgensen, C. J., Struwe, S., and Elberling, B.: Temporal trends in $\mathrm{N}_{2} \mathrm{O}$ flux dynamics in a Danish wetland - effects of plantmediated gas transport of $\mathrm{N}_{2} \mathrm{O}$ and $\mathrm{O}_{2}$ following changes in water level and soil mineral-N availability, Glob. Change Biol., 18, 210-222, 2012.

Kandel, T. P., Elsgaard, L., Karki, S., and Lærke, P. E.: Biomass yield and greenhouse gas emissions from a drained fen peatland cultivated with reed canary grass under different harvest and fertilizer regimes, Bioenergy Res., 6, 883-895, 2013a.

Kandel, T. P., Elsgaard, L., and Lærke, P. E.: Measurement and modelling of $\mathrm{CO}_{2}$ flux from a drained fen peatland cultivated with reed canary grass and spring barley, GCB Bioenergy, 5, 548-561, 2013 b.

Kao-Kniffin, J., Freyre, D. S., and Balser, T. C.: Methane dynamics across wetland plant species, Aquat. Bot., 93, 107-113, 2010.

Karki, S., Elsgaard, L., Audet, J., and Lærke, P. E.: Mitigation of greenhouse gas emissions from reed canary grass in paludiculture: effect of groundwater level, Plant Soil, 383, 217-230, 2014.

Kercher, S. M. and Zedler, J. B.: Flood tolerance in wetland angiosperms: a comparison of invasive and noninvasive species, Aquat. Bot., 80, 89-102, 2004.

Kjaergaard, C., Heiberg, L., Jensen, H. S., and Hansen, H. C. B.: Phosphorus mobilization in rewetted peat and sand at variable flow rate and redox regimes, Geoderma, 173, 311-321, 2012.

Klemedtsson, L., Von Arnold, K., Weslien, P., and Gundersen, P.: Soil CN ratio as a scalar parameter to predict nitrous oxide emissions, Glob. Change Biol., 11, 1142-1147, 2005.

Kuzyakov, Y.: Sources of $\mathrm{CO}_{2}$ efflux from soil and review of partitioning methods, Soil Biol. Biochem., 38, 425-448, 2006.

Kuzyakov, Y., Ehrensberger, H., and Stahr, K.: Carbon partitioning and below-ground translocation by Lolium perenne, Soil Biol. Biochem., 33, 61-74, 2001.

Laanbroek, H. J.: Methane emission from natural wetlands: interplay between emergent macrophytes and soil microbial processes. A mini-review, Ann. Bot., 105, 141-153, 2010.

Lafleur, P. M., Moore, T. R., Roulet, N. T., and Frolking, S.: Ecosystem respiration in a cool temperate bog depends on peat temperature but not water table, Ecosystems, 8, 619-629, 2005.

Lai, D. Y. F.: Methane dynamics in northern peatlands: A review, Pedosphere, 19, 409-421, 2009.

Lloyd, J. and Taylor, J. A.: On the temperature dependence of soil respiration, Funct. Ecol., 8, 315-323, 1994.

Maljanen, M., Komulainen, V.-M., Hytönen, J., Martikainen, P. J., and Laine, J.: Carbon dioxide, nitrous oxide and methane dynamics in boreal organic agricultural soils with different soil characteristics, Soil Biol. Biochem., 36, 1801-1808, 2004.

Maljanen, M., Sigurdsson, B. D., Guðmundsson, J., Óskarsson, H., Huttunen, J. T., and Martikainen, P. J.: Greenhouse gas balances of managed peatlands in the Nordic countries - present knowledge and gaps, Biogeosciences, 7, 2711-2738, doi:10.5194/bg7-2711-2010, 2010.

Maurer, D. A., Lindig-Cisneros, R., Werner, K. J., Kercher, S., Miller, R., and Zedler, J. B.: The Replacement of Wetland 
Vegetation by Reed Canarygrass (Phalaris arundinacea), Ecol. Restor., 21, 116-119, 2003.

Maxwell, S. E. and Delaney, H. D.: Designing experiments and analyzing data: A model comparison perspective, Psychology Press, 2004.

Myhre, G., Shindell, D., Bréon, F.-M., Collins, W., Fuglestvedt, J., Huang, J., Koch, D., Lamarque, J.-F., Lee, D., Mendoza, B., Nakajima, T., Robock, A., Stephens, G., Takemura, T., and Zhang, H.: Anthropogenic and natural radiative forcing, in: Climate change 2013: The physical science basis. Contribution of working group I to the fifth assessment report of the Intergovernmental Panel on Climate Change, edited by: Stocker, T. F., Qin, D., Plattne, G.-K., Tignor, M., Allen, S. K., Boschung, J., Nauels, A., Xia, Y., Bex, V., and Midgley, P. M., Cambridge University Press, Cambridge, United Kingdom and New York, NY, USA, 658-740, 2013.

Parish, F., Sirin, A., Charman, D., Joosten, H., Minayeva, T., Silvius, M., and Stringer, L.: Assessment on peatlands, biodiversity and climate change: main report, Global Environment Centre, Kuala Lumpur and Wetlands International, Wageningen, 2008.

Pedersen, A. R., Petersen, S. O., and Schelde, K.: A comprehensive approach to soil-atmosphere trace-gas flux estimation with static chambers, Eur. J. Soil Sci., 61, 888-902, 2010.

Petersen, S. O., Hoffmann, C. C., Schäfer, C.-M., BlicherMathiesen, G., Elsgaard, L., Kristensen, K., Larsen, S. E., Torp, S. B., and Greve, M. H.: Annual emissions of $\mathrm{CH}_{4}$ and $\mathrm{N}_{2} \mathrm{O}$, and ecosystem respiration, from eight organic soils in Western Denmark managed by agriculture, Biogeosciences, 9, 403-422, doi:10.5194/bg-9-403-2012, 2012.

R Core Team: R: A language and environment for statistical computing. $\mathrm{R}$ foundation for statistical computing, Vienna, Austria, 2013.

Regina, K., Syväsalo, E., Hannukkala, A., and Esala, M.: Fluxes of $\mathrm{N}_{2} \mathrm{O}$ from farmed peat soils in Finland, Eur. J. Soil Sci., 55, 591-599, 2004.

Risk, N., Snider, D., and Wagner-Riddle, C.: Mechanisms leading to enhanced soil nitrous oxide fluxes induced by freeze-thaw cycles, Can. J. Soil Sci., 93, 401-414, 2013.

Riutta, T., Laine, J., and Tuittila, E.-S.: Sensitivity of $\mathrm{CO}_{2}$ exchange of fen ecosystem components to water level variation, Ecosystems, 10, 718-733, 2007.
Roobroeck, D., Butterbach-Bahl, K., Brüggemann, N., and Boeckx, P.: Dinitrogen and nitrous oxide exchanges from an undrained monolith fen: short-term responses following nitrate addition, Eur. J. Soil Sci., 61, 662-670, 2010.

Saari, P., Saarnio, S., Heinonen, J., and Alm, J.: Emissions and dynamics of $\mathrm{N}_{2} \mathrm{O}$ in a buffer wetland receiving water flows from a forested peatland, Boreal Environ. Res., 18, 164-180, 2013.

Schäfer, C. M., Elsgaard, L., Hoffmann, C. C., and Petersen, S. O.: Seasonal methane dynamics in three temperate grasslands on peat, Plant Soil, 357, 339-353, 2012.

Shurpali, N. J., Hyvönen, N. P., Huttunen, J. T., Biasi, C., Nykänen, H., Pekkarinen, N., and Martikainen, P. J.: Bare soil and reed canary grass ecosystem respiration in peat extraction sites in Eastern Finland, Tellus B, 60, 200-209, 2008.

Silvan, N., Regina, K., Kitunen, V., Vasander, H., and Laine, J.: Gaseous nitrogen loss from a restored peatland buffer zone, Soil Biol. Biochem., 34, 721-728, 2002.

Ström, L., Ekberg, A., Mastepanov, M., and Røjle Christensen, T.: The effect of vascular plants on carbon turnover and methane emissions from a tundra wetland, Glob. Change Biol., 9, 11851192, 2003.

Sutton-Grier, A. E. and Megonigal, J. P.: Plant species traits regulate methane production in freshwater wetland soils, Soil Biol Biochem., 43, 413-420, 2011.

Tuittila, E.-S., Komulainen, V.-M., Vasander, H., Nykänen, H., Martikainen, P. J., and Laine, J.: Methane dynamics of a restored cutaway peatland, Glob. Change Biol., 6, 569-581, 2000.

Van Huissteden, J., van den Bos, R., and Alvarez, I. M.: Modelling the effect of water-table management on $\mathrm{CO}_{2}$ and $\mathrm{CH}_{4}$ fluxes from peat soils, Neth. J. Geosci, 85, 3-18, 2006.

Whalen, S. C.: Biogeochemistry of methane exchange between natural wetlands and the atmosphere, Environ. Eng. Sci, 22, 73-94, 2005.

Wichtmann, W. and Tanneberger, F.: Landuse options for rewetted peatlands, in: Carbon credits from peatland rewetting, Climate, biodiversity, land use, edited by: Tanneberger, F., and Wichtmann, W., Stuttgart, Schweizerbart Science Publishers, 107-132, 2011. 